\title{
Little High, Little Low: Girls' and Boys' Academic Self-concept and Performance in English as a Foreign Language
}

\author{
Stephen P. Hughes \\ University of Granada \\ CARMEN Fuentes-Fuentes \\ University of Granada
}

Received: 08 May 2017 / Accepted: 20 July 2017

ISSN: $1697-7467$

\begin{abstract}
The relationship between self-concept and performance in education is a complex one and results from research on this matter are, at times, contradictory. The aim of this study is to analyse differences in perceptions between male and female students in terms of their academic self-concept and their actual performance in English as a Foreign Language (EFL). A total of 110 upper secondary students in Granada, Spain, provided personal perspectives into their perceived strengths and weaknesses in discrete communicative language skills in English and reported on their academic performance in this subject. Results show differences between boys' and girls' perceptions, whereby female participants in the study have relatively higher levels of motivation but also increased levels of anxiety; in addition, females expressed a poorer view on their academic performance in the different language skills in comparison to males, despite the fact that girls' actual performance in assessments was slightly better. The study tentatively concludes that the analysis of student perceptions on their own mastery of skills, as well as their affective attachment towards the language, may provide useful information for teachers.
\end{abstract}

Keywords: language learning, gender, motivation, anxiety, academic performance.

Un poco arriba, un poco abajo: auto-concepto y rendimiento académicos entre alumnos y alumnas de inglés como lengua extranjera

RESUMEN: La relación entre auto-concepto y rendimiento en la educación es una cuestión compleja y a veces contradictoria. El propósito de este estudio es el de analizar las diferencias en percepciones entre alumnos y alumnas en términos de su auto-concepto y rendimiento real en la asignatura de inglés como lengua extranjera. En total, 110 estudiantes del último curso de Bachillerato proporcionaron sus perspectivas personales sobre sus fortalezas y debilidades percibidas en las destrezas comunicativas en inglés; asimismo, proporcionaron información sobre sus resultados académicos en esta asignatura. Los resultados muestran diferencias entre las percepciones de chicos y chicas, donde se detecta una tendencia para las alumnas a tener niveles de motivación más altos, pero también niveles más elevados de ansiedad. Por otra parte, las alumnas expresaron un auto-concepto académico más negativo en cuanto a las destrezas comunicativas en comparación con los alumnos, y eso a pesar de obtener mejores resultados en las evaluaciones. El estudio concluye de manera tentativa que las percepciones del alumnado y su conexión afectiva con el idioma puede proporcionar información de utilidad para el profesorado.

Palabras clave: aprendizaje de la lengua extranjera, género, motivación, ansiedad, rendimiento académico. 


\section{INTRODUCTION}

The present study examines the differences between boys and girls in relation to their own self-concept and levels of performance in the subject area of English as a Foreign Language (EFL). In terms of general education, academic self-concept and performance are viewed as having mutually reinforcing effects (Marsh \& Craven 1997; 2006). Similarly, in language learning contexts, students self-perception is also seen to have an impact on performance (MacIntyre \& Gardner, 1994; Matsuda \& Gobel, 2004) although this impact is not always significant (see, for example Arnaiz \& Guillen, 2012).

In discussing self-concept gender also comes into the picture because it constitutes an essential variable in terms of learners' individual differences (see Kobayashi, 2002; Carrs \& Pawels, 2006). For several decades, experts (e.g. Bacon, 1992; Kissau, 2006) have found interesting differences between males and females in relation to their perceptions towards the foreign language; these differences have included different levels of motivation and anxiety as well as varying degrees of confidence or insecurity, which fluctuate depending on the skill being analysed.

While there have been a number of studies that deal with gender in language learning, there have been relatively few which examine the links between gender and performance (both real and perceived). This study, then, aims to shed some light on how these differences are produced and the relationship that can be found between different levels of anxiety, motivation, confidence and language performance between male and female students.

In order to carry out this analysis there will be a brief review of a number of relevant studies related to perceptions towards EFL together with the effect of the most salient affective variables. In addition, there will be an examination of the concept of gender and a number of studies that have been carried out in relation to this variable. After this review we present our study conducted with 110 students from upper secondary Education in a School in the town of Granada, Spain, which collected answers from open and closed questions dealing with self-concept and the four major language skills (listening, speaking, reading and writing).

\section{Gender and Language Learning}

Several authors, (Kissau, 2006; Warrington \& Younger, 2000) consider gender to be an important aspect of individual student differences; as a result, gender influences and is influenced by many other variables. In language learning, it seems that this field has been traditionally considered to belong to the feminine sphere, as noted by Decke-Cornill and Volkmann (2007) (op. cit. Lu and Luk, 2007), which means that males often see languages as something that does not really apply to their identity as "boys" or "men". This perception is reiterated in Carr and Pawels' (2006) work, where they state that boys see languages as something that does not completely belong to their "normal" curriculum. It may be useful to take these gendered constructions into account, particularly since adolescents are often sensitive to what others think about them and feel easily embarrassed when they are the object of criticism or disdain (see Rankin et al., 2004). 


\subsection{Gender and education in the Spanish context}

As in many other social contexts, Spain has historically experienced gender inequality, which has affected boys' and girls' academic achievement. Martínez García (2010) concedes that girls' educational activity in Spain has passed from being scarce and poor to being as productive and valuable as boys'. Indeed, recent results from PISA (OECD, 2016), for example, reflect a changing trend in Spain as it shows girls outperforming boys in the area of reading, although boys still obtain higher scores in the areas of math and science.

In the specific situation of language and gender in southern Spain, Uribe and Madrid (2008) provide evidence that points to girls having a more positive attitude towards English than boys. These individual differences regarding self-concept have also been analyzed by Padilla Carmona et al. (2010) in a study carried out in Huelva with students in fourth grade of secondary education. Results showed that girls had a higher academic self-concept, whereas boys seemed to feel more comfortable socially, physically and emotionally. Nevertheless, these data also showed a tendency for girls to feel more anxious than boys, which according to the author, could mean that, even though females obtained better results, they perceived that their academic competence as being worse.

\subsection{The four skills}

It could be argued that students' willingness to use the language, especially in front of their peers, might be affected by their perception on their speaking performance. Several studies contend that this skill, together with communication-type activities, is considered to be one of the most anxiety-provoking of the whole skills spectrum (see Kim, 2009). The correlation between anxiety and willingness to participate in oral communication activities is also seen in Baker and MacIntyre's (2000) study. Similarly, in Russell and Cahill-O'Callaghan (2015), students showed high levels of anxiety and low levels of confidence particularly in the case of females. In their research, they concluded that girls felt higher levels of anxiety and lower levels of confidence when it came to speaking.

Even though most studies cited above agree that girls experience more anxiety and lack of confidence than boys, it could be argued that girls' lower levels of confidence in speaking may be related to the lack of attention they sometimes receive in the classroom in comparison to boys. In her study, Martin (2013) indicates that teachers paid more attention to boys both for positive and negative feedback, while girls were expected to be quieter in class, and were slower in giving answers when asked.

In terms of writing, Pajares and Valiante (1999) carried out a study in which girls perceived themselves as having a higher writing competence and higher levels of appreciation towards this skill than boys. In this study, there were no significant differences in terms of self-efficacy and writing apprehension, however, in later research by the same authors (Pajares \& Valiante, 2001) girls experienced less anxiety in relation to writing, although writing performance was the same for both boys and girls.

In a study by Graham et. al. (2007), although girls showed better writing skills and a more positive attitude, no statistically significant differences were found. On the other hand, a number of studies on boys' and girls' perceptions regarding writing show that males tend to be more confident in their writing abilities, whereas females are usually more modest 
when expressing their perceived writing efficacy (Wigfield, Eccles, \& Pintrich, 1996, op. cit. Pajares \& Valiante, 1999). In general, it seems to be the case that girls often see themselves as better writers than boys, although results on self-efficacy and writing performance do not always vary significantly between both groups.

As far as reading is concerned, in Lu and Luk's (2014) study, where they interviewed two low-achieving males and two high-achieving females regarding reading skills, participating females valued reading much more than male peers and performed better; at the same time, the male interviewees considered reading hard and boring. Moreover, one of the male students reported reading to be a "passive" activity, as opposed to the more "active" ones, which, as a man, were more appropriate and interesting for him. The results of another larger study conducted by Chiu and McBride-Chang (2006) in 43 different countries mirrored those of $\mathrm{Lu}$ and Luk's study; in every country, girls outperformed boys in reading skills; at the same time, reading enjoyment was the only variable that mediated the effects produced by gender.

As for listening, this skill is often regarded as one of the most difficult for learners to develop and for their teachers to assess (Chang \& Read, 2006: 375). This may be one of the reasons why literature on listening and students' perception seems to be very scarce. According to Bembenutty (2007), Kissau (2006) and Klassen (2002) gender is an important variable to take into account when analyzing listening skills and strategies since men and women have different beliefs when it comes to self-efficacy and motivation in this area (op. cit. Nix and Tseng, 2014). A study carried out by Bacon (1992) showed the differences between men and women regarding their affective response and perceptions when confronted with authentic listening material. Participants listened to two oral texts, the first being noticeably more difficult than the second. Results showed that women experienced more negative feelings after listening to the most difficult passage, whereas men seemed to be more consistent regarding their listening abilities and showed more positive feelings. As a result, it seems that, just like speaking, listening may be perceived more positively or optimistically by men in relation to their self-efficacy.

\section{Methods, instruments, PARTiCipants AND PROCEDURes}

As previously mentioned, a number of studies have considered motivation, anxiety and performance to be important variables when measuring students' perceptions towards second language learning. The research questions for this study in particular are:

1. Are there significant differences between male and female students in terms of levels of anxiety and motivation when learning a language?

2. Are there significant differences between male and female students in terms of perceived usefulness of individual skills when learning a language?

In order to answer these questions a questionnaire was designed with 6 sections, where the areas mentioned would be explored in relation to the four skills. This questionnaire was developed based on an extensive literature review including Kobayashi, 2002; Lu and Luk, 2014; Bandura, 1999; Gu, 2002; Kissau, 2006; Rushidi, 2012; Bacon, 1992; Carr and 
Pawels, 2006; Nix and Tseng, 2014. In order to avoid an excessively long questionnaire, the instrument included four sections (one per skill) containing 10 closed items, scored by the participants through a five-point Likert scale (from 1, totally disagree to 5, totally agree). In order to gain additional information and possible explanations for answers, students also answered a series of open questions where they could state what they liked most and least about working with each skill.

Participation in the study took place with four final year groups of upper secondary education in a school in Granada, southern Spain. A total of 110 student volunteers (48 male; 61 female; 1 'no answer') completed the questionnaire anonymously during their English class under the supervision of a researcher from the University of Granada. Bio-data gathered from participants to control for other possible differences included information, such as whether or not they received private tuition in English outside school, if they studied social sciences, humanities subjects or science subjects and if they were part of the school bilingual program. In addition, students provided their most recent assessment scores for the subject of English.

Completion of the questionnaire took approximately 15 minutes. Quantitative data were subsequently introduced using the SPSS program (Version 20). Since the questionnaire contained positively and negatively worded items, the latter items were temporarily recoded positively in order to conduct tests on internal reliability using a Cronbach alpha procedure. Once this analysis was produced, descriptive analyses were conducted to calculate participants' general mean scores and standard deviation. In order to find any significant differences between the genders $(p$ value $<0,05)$ a T-Test was conducted.

Qualitative data (students' responses to the open questions) were transcribed and recorded in an excel file; these answers were then summarized and placed in groups with similar content areas. In order to find patterns in the qualitative responses, a number of categories were established (see Saldaña, 2011; Hughes \& Tulimirovic, 2015); this included finding answers which were similar enough to be grouped together and placed under the same category according to the nature of those answers, together with the decision not to include those answers which were not relevant to the research questions. This allowed for different categories in all four sections, which permitted the researchers to compare boys' and girls' statements.

\section{Results}

The first step taken to analyze the quantitative data provided in the questionnaire was to carry out an internal reliability analysis. To do this, each statement was labelled with a letter and a number: the speaking section was labelled from A1 to A10, writing was labelled from $\mathrm{B} 1$ to $\mathrm{B} 10$, reading from $\mathrm{C} 1$ to $\mathrm{C} 10$, and listening from $\mathrm{D} 1$ to $\mathrm{D} 10$. One aspect to take into account is the fact that 4 out of 10 statements in each section were negative, whereas the rest were positive, which meant that these items had to be positively recoded in order to be measured together. Reliability tests (Table 1) were carried out afterwards, taking into account the areas mentioned above which are present in all sections in the same items: anxiety (1, 4 and 5), motivation (8, 9, and 10), performance (2, 3, and 6), and usefulness (7). 
Table 1. Reliability analysisç

\begin{tabular}{lc}
\hline \multicolumn{1}{c}{ Area } & Cronbach alpha \\
\hline Anxiety (questions 1, 4 and 5 of each section) & 0.744 \\
Motivation (questions 8, 9 and 10 of each section) & 0.770 \\
Performance (questions 2, 3 and 6 of each section) & 0.920 \\
Usefulness (question 7 of each section) & 0.727 \\
\hline
\end{tabular}

In addition to these four areas, participants also provided information as to the average score they had obtained in their last English assessments on a scale of 1-10. The average scores for boys was 6.96 , while the average score for girls was slightly higher, at 7.17. In terms of other control variables, no significant differences were found between students who attended private classes or students who formed part of the bilingual project.

\subsection{Closed questions}

The descriptive analysis (Table 2) calculated the standard deviation and the mean scores for the four skills. Participants' highest mean scores in all four skills were given to item 7 (usefulness) (mean $\geq 4.60$ ), whereas the lowest score was given to item 10 (reluctance) (means $\leq 2.15$ ). Comparing the four areas in each section, participants reported highest scores in anxiety in speaking (means $\geq 3.20$ ). The skill which is reported to be the one where they felt less insecurity was reading $($ mean $=2.27)$. In relation to motivation, highest scores were given to listening (mean $=4.27$ ), and students indicated highest scores in reluctance (item 10) in the writing section (mean $=2.15$ ). Reading was the highest scored section when participants were asked about their performance (mean $\geq 2.50$ ), and speaking was also the skill which participants perceived as most useful (mean $=4.92)$.

Table 2. Overall mean scores and Standard deviation in translated items

\begin{tabular}{lcc}
\hline \multicolumn{1}{c}{ Item } & Mean & S.D. \\
\hline Speaking & & \\
A1. I feel nervous when talking in English in front of classmates & 3.26 & 1.202 \\
A2. I think I speak English well & 3.20 & .880 \\
A3. I think I speak English better than my classmates & 2.54 & .983 \\
A4. I don't feel confident when I have to speak English & 3.21 & 1.139 \\
A5. I don't care about making mistakes when I speak in English & 3.04 & 1.013 \\
A6. Speaking English is easy for me & 3.15 & 1.051 \\
A7. Speaking English is important & 4.92 & .362 \\
A8. I only like speaking in English about topics that interest me & 2.47 & .939 \\
A9. I'm interested in speaking English about any topic & 3.61 & 1.041 \\
A10. I feel unenthusiastic when I have to speak in English & 1.79 & .705
\end{tabular}




\section{Writing}

B1. I feel nervous when writing in English and I know I'm going to be assessed

B2. I think I write well in English

B3. I think I write in English better than my classmates

B4. I don't feel confident when I have to write in English

B5. When I want to express myself in written English, I don't feel nervous

B6. Writing in English is easy for me

B7. Writing in English is important

B8. I only like writing in English about topics that interest me

B9. I practise writing at home (blogs, poetry, stories, etc.)

$2.38 \quad 1.078$

B10. I feel unenthusiastic when I have to write in English

\section{Reading}

C1. I feel frustrated when I read in English and can't understand everything

C2. I think my reading comprehension in English is good

C3. I think my English reading comprehension is better than my classmates

C4. I don't feel confident when I have to read a text in English

C5. I don't care about not understanding everything

C6. Reading in English is easy for me

C7. Having a good level of reading comprehension in English is important

C8. I only like to read texts in English about topics that interest me

C9. I'm interested in reading books/ magazines/ articles in English

\section{Listening}

D1. I feel frustrated when I listen to in English and can't understand everything

D2. I understand everything or almost everything when I listen in English

D3. I think my listening comprehension is better than my classmates

D4. I don't feel confident when I have to listen in English

D5. I don't care about not understanding everything when I listen in English

D6. Listening in English is easy for me

D7. Having a good level of listening comprehension is important

D8. I only like to listen when it is about topics that interest me 
The results obtained by the descriptive analysis and the T-Test to locate significant differences between boys and girls can be found in Table 3 .

Table 3.T-Test comparing mean scores for boys and girls

\begin{tabular}{lcccc}
\hline & Mean scores & $\begin{array}{c}\text { Levene test for } \\
\text { comparison of } \\
\text { variances }\end{array}$ & $\begin{array}{c}\text { T-Test for } \\
\text { comparison } \\
\text { of means }\end{array}$ \\
& Male & Female & & \\
& & & & \\
& & & & $\begin{array}{c}\text { p-value } \\
\text { lateral)* }\end{array}$ \\
\hline $\begin{array}{l}\text { A1 Speaking: I feel nervous when talking in } \\
\text { English in front of classmates }\end{array}$ & 2.90 & 3.56 & 0.021 & 0.003 \\
$\begin{array}{l}\text { A3 Speaking: I think I speak English better } \\
\text { than my classmates }\end{array}$ & 2.81 & 2.33 & 0.221 & 0.01 \\
$\begin{array}{l}\text { A4 Speaking: I don't feel confident when I } \\
\text { have to speak English }\end{array}$ & 2.91 & 3.46 & 0.569 & 0.013 \\
$\begin{array}{l}\text { B3 Writing: I think I write in English better } \\
\text { than my classmates }\end{array}$ & 2.71 & 2.28 & 0.226 & 0.022 \\
$\begin{array}{l}\text { B10 Writing: I feel unenthusiastic when I } \\
\text { have to write in English }\end{array}$ & 2.5 & 1.9 & 0.109 & 0.001 \\
$\begin{array}{l}\text { C3Reading: I think I English reading compre- } \\
\text { hension is better than my classmates }\end{array}$ & 2.79 & 2.39 & 0.09 & 0.037 \\
$\begin{array}{l}\text { D9 Listening: I'm interested in listening to } \\
\text { songs/watch series, films in English }\end{array}$ & 4.04 & 4.46 & 0.626 & 0.027 \\
\hline
\end{tabular}

In Table 3 the Levene test is employed to assess the equality of variances and, consequently, to choose the parametric test to compare measures (T-Test) assuming similar or different variances. As can be observed, significant differences between mean scores ( $p \leq$ 0.05 ) were found in items $\mathrm{A} 1, \mathrm{~A} 3$ and $\mathrm{A} 4$, which have to do with anxiety and perceived performance. Girls scored significantly higher than boys (3.56 vs. 2.90) when asked if they felt nervous when they spoke in English in front of their classmates (A1). Similarly, when asked if they felt confident when speaking (A4), statistically significant differences were also found between groups, with girls expressing a greater lack of confidence (3.46 vs. 2.91). In contrast, however, as seen in Item A3, boys' self-perception in terms of oral competence was higher (2.81 vs. 2.33). As seen in Item B3, for writing, boys again show higher levels of confidence in their abilities in this skill (2.71 vs. 2.28). Levels of motivation or enthusiasm towards writing (B10), however, are significantly lower for boys (2.5 vs. 1.9). Statistically significant differences between both groups were also found in item $\mathrm{C} 3$ in the reading section, which indicates that, once again, boys' perception of their reading skills are higher than 
girls' (2.79 vs. 2.39). Finally, while there were no significant differences in self-perception in terms of performance for the listening skill (D9), girls indicated higher levels of interest in listening to English outside the class (4.46 vs. 4.04).

\subsection{Open questions}

This section will deal with participants' responses to the eight open questions provided in the questionnaire. As previously noted, there were two open questions in each section: the aim of the first question was to find out what participants' liked about that skill in particular, whereas the second one asked about what participants liked least about that skill. Table 4 provides a summary of categorised answers provided by at least 3 students.

Table 4. Positive and negative aspects of the four skills

\begin{tabular}{|c|c|c|c|c|c|}
\hline \multicolumn{3}{|c|}{ What do you like the most about speaking? } & \multicolumn{3}{|c|}{ What do you like the least about speaking? } \\
\hline Category & Girls & Boys & Category & Girls & Boys \\
\hline To be understood/communicate & 23 & 22 & Being wrong. Making mistakes. & 15 & 6 \\
\hline I like it & 6 & 2 & Being unable to say something. & 17 & 15 \\
\hline Learning. Improving & 17 & 6 & No fluency. & 8 & 7 \\
\hline Useful. Important & 6 & - & Pronunciation & 5 & 3 \\
\hline \multirow[t]{3}{*}{ New. Different } & 2 & 4 & Nervousness. Public speaking & 14 & 7 \\
\hline & & & Topic & 2 & 4 \\
\hline & & & Grammar and vocabulary & 6 & 4 \\
\hline \multicolumn{3}{|c|}{ What do you like the most about writing? } & \multicolumn{3}{|c|}{ What do you like the least about writing? } \\
\hline Category & Girls & Boys & Category & Girls & Boys \\
\hline Expressing myself & 16 & 10 & Being wrong & 10 & 3 \\
\hline Expressing my ideas/opinions & 2 & 6 & Being unable to say something, & 15 & 11 \\
\hline I like it & 2 & 3 & Lack of vocabulary, grammar & 8 & 15 \\
\hline Usefulness & - & 4 & Topic & 2 & 3 \\
\hline Learning. Practising. Improving & 10 & 7 & Difficulty & 1 & 3 \\
\hline Grammar and vocabulary & 7 & 3 & I do not like it & 1 & 3 \\
\hline Comparison with "speaking" & 9 & 5 & Insecurity & 5 & 2 \\
\hline Difficulty (easier) & 3 & - & Spelling & - & 3 \\
\hline Topic & 3 & 3 & Comparison to speaking & - & 3 \\
\hline Enjoy using the language & 4 & - & Having to think more & 2 & 1 \\
\hline
\end{tabular}




\begin{tabular}{lcclccc}
\hline \multirow{2}{*}{ What do you like the most about reading? } & \multicolumn{2}{l}{ What do you like the least about reading? } \\
Category & Girls & Boys & Category & Girls & Boys \\
\hline Learning expressions, grammar & 25 & 13 & Understanding & 13 & 10 \\
Pronunciation & 2 & 1 & Understanding everything & 2 & 3 \\
Improving & 3 & 2 & Learning. Practising. Improving. & 16 & 6 \\
Understanding the language & 16 & 6 & Learning pronunciation & 16 & 1 \\
Understanding everything & 1 & 2 & I like it & 5 & - \\
Understanding most things & 2 & 1 & Songs/ films/native accent & 17 & 15 \\
I like it & 3 & 3 & Satisfaction & 1 & 2 \\
Access to new information & 7 & 9 & & & \\
Topic & 4 & 6 & & & \\
\hline What do you like the most about listening? & What do you like the least about listening? \\
Category & Girls & Boys & Category & Girls & Boys \\
\hline Understanding & 13 & 10 & Not understanding & 22 & 12 \\
Understanding everything & 2 & 3 & Not understanding everything & 4 & 3 \\
Learning. Practising. & 16 & 6 & Not understanding anything & - & 5 \\
Learning pronunciation & 16 & 1 & Not understanding word & 6 & 5 \\
I like it & 5 & - & Not understanding accent & 9 & 5 \\
Songs/ films / native accent & 17 & 15 & Not understanding some things & 1 & 4 \\
Satisfaction & 1 & 2 & Not understanding due to speed & 9 & 5 \\
\hline
\end{tabular}

In terms of speaking, girls were more likely to express enjoyment in expressing themselves in the target language; moreover, they were more prone to saying that it helped them to learn and improve. Boys and girls frequently expressed not liking the fact that they could not always express themselves accurately and fluently; girls however, seemed to feel less comfortable when it came to making mistakes.

With the writing skill, a similar percentage of boys and girls expressed that they liked to write and it helped them to learn and practice. Several students compared writing to speaking in the sense that they believed that writing was easier and less stressful, especially girls ( 9 girls vs. 5 boys); girls also seemed to like being able to communicate through writing more than boys. On the other hand, several boys in this sample expressed that they liked the fact that they could express their own thoughts and opinions using this skill (6 boys vs. 2 girls). As far as negative aspects in writing are concerned, both groups frequently expressed not liking being inaccurate and having 'mental blocks'; again, girls tended to report more frequently that they did not like making mistakes in their writing. A possible noteworthy point here is that boys were more likely to express their dissatisfaction when it came to making mistakes in grammar and vocabulary. 
With reading, both male and female students seemed to appreciate the fact that this skill gave them access to information and texts they could not find in their mother tongue. Here, the most noteworthy difference, perhaps, was that girls were more likely to report that they liked learning new vocabulary and expressions as well as grammar when reading ( 25 girls vs. 13 boys). When it comes to reading comprehension, girls were more likely to express dissatisfaction at not being able to understand texts (14 girls vs. 7 boys).

In terms of listening, both male and female participants seemed to enjoy understanding English in its spoken form; a greater number of girls, however, expressed that they enjoyed practising and improving their listening skills (16 girls vs. 6 boys). Additionally, several female participants reported enjoying listening activities in general, whereas boys did not mention this ( 5 vs. 0$)$. Many more girls than boys (22 vs. 12) reported dissatisfaction at not understanding in general, whereas a few boys but no girls ( 5 vs. 0 ) disliked not understanding anything at all. Some boys' answers seemed to indicate that they felt listening required too much effort. Accent and speed also seemed to be an issue for some of the participants, with girls reporting this perception more frequently ( 9 girls vs. 5 boys). Interestingly, two girls mentioned words related to stress (in Spanish 'estrés' and 'agobio'), while other girls mentioned that they felt a sense of insecurity.

\section{Conclusions}

This study has attempted to examine the perception of male and female students in terms of their levels of motivation, confidence and competence in English as a foreign language. Before beginning to provide a number of tentative conclusions, it is important to remember that the study has a number of limitations. Firstly, given the non-probabilistic sample, results are not generalisable; similarly, participants came from one academic level at the end of secondary education and, thus, the study did not cover a wider spectrum of secondary school students. While keeping these constraints in mind, it is possible that the results from this study in language learning might possibly reflect a larger pattern with students from similar backgrounds.

Perhaps the most interesting finding in this study lies in the fact that girls report that they obtain higher scores in assessments of English than boys; yet despite this small difference in favour of girls, boys have statistically significant higher levels of perceived achievement in speaking, reading and writing. Girls, on the other hand, show higher levels of anxiety and motivation and these differences are statistically significant when it comes to nervousness and lack of confidence about speaking on the one hand, but higher levels of enthusiasm towards speaking and listening on the other. It could be the case that girls' willingness to perform well in English also increases their levels of anxiety and the belief that they may not be able to reach expected standards. Girls seem more pessimistic, while boys are much more optimistic about their self-efficacy in this particular sample, and this could be the reason behind the different levels of anxiety between groups. Here, boys show low levels of anxiety, but also of motivation; in general they demonstrate a very optimistic view of their English performance, even though their actual performance is slightly lower. Girls on the other hand perform slightly better and are more motivated but they are also less confident and more anxious. 
Some tentative pedagogical implications could be deduced, then, from the previously outlined ideas. Firstly, anxiety may work for some students to achieve good academic results, but others may feel too anxious to attain good performance levels. Insecurity may not always be a good path for learning, and it can encourage certain psychological attitudes which may not be useful for the learners in their future lives. Teachers might wish to make efforts to know how to filter this negative influence that anxiety may produce and to be aware of the possible tendency for girls in particular to experience nervousness and a lack of confidence.

On the other hand, significantly lower scores on the part of boys in terms of their levels of enthusiasm or motivation in skills such as listening, reading or writing would perhaps suggest that there is a continued need to help male learners see the value and usefulness of these skills and to make any related activities as purposeful, meaningful and motivating as possible. At the same time, teachers may see the usefulness of enabling students to see their performance in a realistic way, and encourage them individually to do as much as their abilities will allow.

The sample surveyed in this study leads us to tentatively conclude that there are discrepancies between students' self-concept and performance in relation to gender: boys believe they are better but have lower scores, while girls are less confident about their abilities but score higher. Similarly, there are a number of differences pertaining to gender in terms of motivation (lower for boys) and anxiety (higher for girls), which could lead us to ask if it is the higher levels of motivation and greater levels of 'concern' about language learning that helps girls to perform better.

Informed teachers are arguably in the best position to address these possible mismatches and to provide balanced and realistic feedback. Similarly, it is teachers who can create positive environments which encourage learners to fully participate in all of the different language skills and to put in place the teaching strategies and learning activities which can help students not only to succeed, but also to be conscious of their success.

\section{REFERENCES}

Arnaiz, P., \& Guillen, F. (2012). "Self-concept in university-level FL learners", in The International Journal of the Humanities, 9,4: 81-92.

Bacon, S. M. (1992). The relationship between gender, comprehension, processing strategies, and cognitive and affective response in foreign language listening. The Modern Language Journal, 76(2), 160-178.

Baker, S. C., \& MacIntyre, P. D. (2000). "The role of gender and immersion in communication and second language orientations", in Language Learning, 50, 2: 311-341. doi: 10.1111/00238333.00224

Bandura, A. (1999). "Social cognitive theory. An agentic perspective", in Asian Journal of Social Psychology, 2,1: 21-41.

Bembenutty, H. (2007). "Self-regulation of learning and academic delay of gratification: Gender and ethnic differences among college students", in Journal of Advanced Academics, 18, 4: 586-616.doi: 10.4219/jaa-2007-553.

Carr, J., \& Pawels, A. (2006). Boys and Foreign Language Learning. Real Boys don't Do Languages. New York: Palgrave Macmillan. 
Chang, A. C. \& Read, J. (2006). "The effects of listening support on the listening performance of EFL learners", in TESOL Quarterly, 40, 2: 375-397. doi: 10.2307/40264527.

Chiu, M. M., \& McBride-Chang, C. (2006). "Gender, context, and reading: a comparison of students in 43 countries", in Scientific Studies of Reading, 10,4: 331-362. DOI: 10.1207/ s1532799xssr1004_1.

Decke-Cornill, H., \& Volkmann, L. (Eds.). (2007). Gender Studies and Foreign Language Teaching. Tübingen, Germany: Narr.

Graham, S., Berninger, V. \& Fan, W. (2007). "The structural relationship between writing attitude and writing achievement in first and third grade students", in Contemporary Educational Psychology, 32: 516-536.

$\mathrm{Gu}$, Y. (2002). "Gender, academic major, and vocabulary learning strategies of Chinese EFL learners", in RELC Journal, 22,1: 35-54. doi: 10.1177/003368820203300102.

Hughes, S. P., \& Tulimirovic, B. (2015). "ICT use and perceived effectiveness in an adult EFL learning context", in Revista de Lenguas para Fines Especificos, 21, 1: 15-40.

Kissau, S. (2006). "Gender differences in second language motivation: An investigation of micro- and macro-level influences", in Canadian Modern Language Review, 62,3: 401-422.

Klassen, R. (2002). "Writing in early adolescence: A review of the role of self-efficacy beliefs", in Educational Psychology Review, 14, 2: 173-203. doi: 10.1023/A:1014626805572.

Kobayashi, Y. (2002)."The role of gender in foreign language learning attitudes: Japanese female students' attitudes towards English learning”, in Gender and Education, 14,2: 181-197. doi: $10.1080 / 09540250220133021$.

Lu, H. \& Luk, J. (2014). "I would study harder if I was a girl: Gendered narratives of lowachieving male and high achieving female EFL learners", in Journal of Language, Identity \& Education, 13,1: 1-15. doi: 10.1080/15348458.2013.835571.

MacIntyre, P. D. \& Gardner, R. C. (1994). "The subtle effects of language anxiety on cognitive processing in the second language", in Language Learning, 44, 2: 283-305. doi:10.1111/j.1467-1770.1994.tb01103.x

Martin, L. W. (2013). Examining gender and cultural influences on classroom participation and interaction of students in an ESL and general education classroom. Master's Project. State University of New York. Retrieved from https://dspace.sunyconnect.suny.edu/bitstream/ handle/1951/63491/Lindsey_Martin_Masters_Project_December2013.pdf?sequence=1.

Martínez García, J. S. (2010). "Género y origen social: diferencias grandes en fracaso escolar administrativo y bajas en rendimiento educativo" in Revista de la Asociación de Sociología de la Educación, 4,3: 270-285.

Matsuda, S. \& Gobel, P. (2004). "Anxiety and predictors of performance in the foreign language classroom", in System 32, 1: 21-36, doi.org/10.1016/j.system.2003.08.002

Nix, J-M. L. \& Tseng, W.T. (2014)."Towards the measurement of EFL listening beliefs with item response theory methods", inInternational Journal of Listening, 28,2: 112-130, doi: 10.1080/10904018.2013.872990.

OECD (2016). PISA 2015 Results (Volume I): Excellence and Equity in Education. Paris: OECD Publishing.

Padilla Carmona, M. T., García Gómez, S., Suárez Ortega, M. (2010). "Diferencias de género en el autoconcepto general y académico de estudiantes de $4^{\circ}$ de ESO", in Revista de Educación, 352, 495-515.

Pajares, F. \& Valiante, G. (1999). "Grade level and gender differences in the writing self-beliefs of middle school students", in Contemporary Educational Psychology, 24, 4: 390-405. doi: 10.1006/ceps.1998.0995. 
Pajares, F. \& Valiante, G. (2001). "Gender differences in writing motivation and achievement of middle school students: A function of gender orientation?", inContemporary Educational Psychology, 24, 4:366-38. doi: 10.1006/ceps.2000.1069.

Rankin, J. L., Lane, D. J., Gibbons, F. X., Gerrard, M. (2004). "Adolescent self-consciousness: longitudinal age changes and gender differences in two cohorts", inJournal of Research on Adolescence, 14,1: 1-21. doi: 10.1111/j.1532-7795.2004.01401001.x.

Rushidi, J. (2012). "Perceptions and performance: students' attitudes towards academic English writing", in Versita, 8, 2: 1-15. doi: 10.2478/v10306-012-0013-6.

Russell, R. \& Cahill-O'Callaghan, R. (2015)."Speaking in the classroom: the impact of gender and affective responses on oral participation", in The Law Teacher, 49(1), 60-72, doi: 10.1080/03069400.2014.988459.

Uribe, D., Gutiérrez, J., \& Madrid, D. (2008). "Las actitudes del alumnado hacia el aprendizaje del inglés como idioma extranjero: estudio de una muestra en el sur de España", in Porta Linguarum, 10, 85-100.

Wigfield, A., Eccles, J. S., \& Pintrich, P. R. (1996). "Development between the ages of 11 and 25", in D. C. Berliner \& R. C. Calfee (eds.), Handbook of Educational Psychology New York: Simon \& Schuster Macmillan,148-185. 